\title{
EFEKTIVITAS KOMPRES JAHE TERHADAP PENURUNAN SKALA NYERI SENDI PENDERITA ASAM URAT DI DESA TEMPUREJO DAN JURUG JUMAPOLO KARANGANYAR
}

\author{
Lilik Sriwiyati $^{1}$, Dwi Noviyanti ${ }^{2}$
}

\begin{abstract}
Background: The uric acid disease continues to increase in prevalence, with the main symptom being severe pain in the joints. One of the non-pharmacological pain management is to use warm compresses, one of which the ingredients can use ginger because ginger contains some substances that can reduce pain. The purpose of this study was to analyze the effectiveness of ginger compress on decreasing the scale of joint pain in people with uric acid in Tempurejo dan Jurug Jumapolo

Subjects of this research : were Tempurejo and Jurug villagers. The samples were 22 respondents selected by using total sampling method. Method of the research is a queasy experiment with pre-post test design. This research has two variables, the independent variable is compressed ginger and the dependent variable is pain scale. Collecting data use observation paper. Data analysis using paired t-test with $\mathrm{p}=0.05$

The result of this research : is the average scale of the pain before giving the ginger compress is 4.18 with standard deviation \pm 1.053 . While the average scale of pain after the ginger compression is done 2.73 with standard deviation \pm 1.162 . The mean difference of pain scale before and after giving ginger compress is 1.455 with standard deviation \pm 0.671 . The $p$-value is 0.000 .

The Conclusion of this research : is a ginger compress effective against the decrease in pain scale of uric acid sufferers on villagers of Tempurejo and Jurug Jumapolo.
\end{abstract}

Keywords: stress level, menstrual cycles

\section{PENDAHULUAN}

Penyakit asam urat terus meningkat prevalensinya, baik di negara maju maupun berkembang dan hanya sedikit penderita asam urat yang terkontrol dengan baik. Di Amerika angka kejadian asam urat mencapai $2-13 \%$. Indonesia menempati peringkat pertama penderita asam urat di Asia Tenggara dengan angka prevalensi 655.745 orang $(0.27 \%)$ dari 238.452.952 orang (Right Diagnosis Statistik, 2010). Berdasarkan hasil Riset Kesehatan Dasar (Riskesdas) Indonesia tahun 2013 prevalensi penderita asam urat di Jawa Tengah sebesar 24.3\% pada laki-laki dan $11.7 \%$ pada perempuan. Asam urat sering terjadi pada usia pertengahan antara 40-59 tahun.
Gambaran klinis adanya asam urat biasanya menyebabkan rasa nyeri yang hebat pada sendi, biasanya disertai peradangan seperti pembengkakan sendi, panas, dan tampak kemerahan. Adanya gejala nyeri pada penderita asam urat dibuktikan oleh Putri, Rahmayanti dan Diani (2017) yang menilai skala nyeri pada 32 penderita asam urat, dan didapatkan hasil bahwa dari 32 responden terdapat 8 responden mengalami nyeri berat dan 24 responden mengalami nyeri sedang. Demikian juga penelitian Rusnoto, Cholifah dan Retnosari (2015) yang mengukur nyeri 30 penderita asam urat berdasarkan usia dan skala nyeri, didapatkan hasil dari 30 responden mayoritas yang mengalami nyeri adalah usia 47-61 tahun sedangkan berdasarkan skala 
nyeri rata-rata skala nyeri yang dialami responden adalah 6 (nyeri sedang) dengan skala tertinggi 8 (nyeri hebat) dan skala nyeri terkecil 3 (nyeri ringan).

Salah satu penatalaksanaan nyeri secara non farmakologi adalah menggunakan kompres hangat (Izza, 2014). Salah satu bahan untuk kompres yang dapat memberikan sensasi hangat adalah jahe. Kandungan jahe bermanfaat untuk mengurangi nyeri pada asam urat karena jahe memiliki sifat pedas, pahit dan aromatik dari olerasin seperti zingeron, gingerol dan shagaol. Olerasin memiliki potensi anti inflamasi, analgetik dan antioksidan yang kuat. Olerasin atau zingerol dapat menghambat sintesis prostalglandin sehingga dapat mengurangi nyeri atau radang.

Berdasarkan wawancara dengan warga terdapat 25 warga yang mengatakan bahwa ia menderita asam urat. Dari 25 warga tersebut yang berkenan untuk dilakukan pengecekan asam urat sejumlah 22 orang, 3 warga lainnya tidak berkenan dicek karena takut dan sudah melakukan pengecekan di puskesmas kurang lebih satu minggu yang lalu. Hasil yang didapatkan setelah melakukan pengecekan asam urat pada 22 orang tersebut seluruhnya mengalami kadar asam urat yang melebihi rentang normal. Gejala yang dirasakan pada umumnya sama, seperti nyeri hebat di kaki, bengkak dan menjalar hingga mengganggu aktivitas. Pada umumnya nyeri tersebut dirasakan pada malam hingga pagi hari atau bahkan seharian penuh. Untuk menangani kondisi tersebut warga mengkonsumsi obat penurun asam urat dari puskesmas, apabila obat dari puskesmas sudah habis, maka warga mengkonsumsi obat-obatan yang dijual di warung. Warga belum mengetahui bahwa kompres jahe dapat menurunkan nyeri akibat asam urat.

Melihat fenomena di atas maka peneliti memandang perlu untuk melakukan penelitian tentang "Efektivitas kompres jahe terhadap penurunan skala nyeri sendi pada penderita asam urat di Desa Tempurejo dan Jurug Kecamatan Jumapolo Kabupaten Karanganyar".

\section{TUJUAN PENELITIAN}

Tujuan penelitian ini adalah untuk menganalisis efektivitas kompres jahe terhadap penurunan skala nyeri sendi pada penderita asam urat di Desa Tempurejo dan Jurug Kecamatan Jumapolo.

\section{METODE/DESAIN PENELITIAN}

Penelitian ini menggunakan desain quasy eksperiment dengan rancangan pre post test design untuk mengetahui efektivitas pemberian kompres jahe terhadap penurunan skala nyeri sendi pada penderita asam urat di Desa Tempurejo dan Jurug Kecamatan Jumapolo Kabupaten Karanganyar. Penelitian ini terdiri dari dua variabel yaitu kompres jahe sebagai variabel bebas (independent variable) dan skala nyeri sebagai variabel terikat (dependent variable).

\section{POPULASI, SAMPEL DAN TEKNIK SAMPLING}

Populasi dalam penelitian ini adalah seluruh penderita asam urat yang berusia 40-60 tahun di Desa Tempurejo dan Jurug Jumapolo Karanganyar yang mengalami nyeri sendi akibat asam urat dengan populasi sebanyak 22 responden. Besar sampel pada penelitian ini adalah 22 orang yang diambil dengan teknik total sampling, karena jumlah sampel yang relatif kecil. 
HASIL PENELITIAN

1. Karakteristik Responden

Tabel 1.

Distribusi Frekuensi

Karakteristik Responden

\begin{tabular}{ccc}
\hline $\begin{array}{c}\text { Karakteristik } \\
\text { Responden }\end{array}$ & $\mathrm{f}$ & $\%$ \\
\hline $\begin{array}{c}\text { Umur (th) } \\
40-49\end{array}$ & 10 & 45.45 \\
$50-60$ & 12 & 54.55 \\
$\begin{array}{c}\text { Jenis kelamin } \\
\text { Laki-laki } \\
\text { Perempuan }\end{array}$ & 9 & 40.90 \\
\hline Jumlah & 13 & 59.10 \\
\hline
\end{tabular}

Tabel di atas menunjukkan bahwa berdasarkan umur responden paling banyak berumur 50-60 tahun yaitu berjumlah $\quad 12 \quad$ (54.55\%) responden sedangkan berdasarkan jenis kelamin paling banyak perempuan dengan jumlah $13(59.10 \%)$ responden.

2. Distribusi Skala Nyeri Sebelum Kompres Jahe

Tabel 2.

Distribusi Frekuensi Skala Nyeri

\begin{tabular}{ccc}
\hline Skala & $\mathrm{f}$ & $\%$ \\
\hline 2 & 1 & 4.5 \\
3 & 5 & 22.7 \\
4 & 7 & 31.8 \\
5 & 7 & 31.8 \\
6 & 2 & 9.1 \\
\hline Total & 22 & 100 \\
\hline
\end{tabular}

Berdasarkan tabel di atas dapat diamati bahwa skala nyeri sendi dari 22 responden yaitu skala 2 sebanyak 1 (4.5\%) responden, skala 3 sebanyak 5 (22.7\%) responden, skala 4 sebanyak 7 $(31.8 \%)$ responden, skala 5 sebanyak 7 (31.8\%) responden, dan skala 6 sebanyak 2 (9.1\%) responden.
3. Distribusi Skala Nyeri Setelah Kompres Jahe

Tabel 3.

Distribusi Frekuensi Skala Nyeri

\begin{tabular}{ccc}
\hline Skala & $f$ & $\%$ \\
\hline 1 & 4 & 18.2 \\
2 & 5 & 22.7 \\
3 & 7 & 31.8 \\
4 & 5 & 22.7 \\
5 & 1 & 4.5 \\
\hline Total & 22 & 100
\end{tabular}

Berdasarkan tabel di atas dapat diamati bahwa skala nyeri sendi dari 22 responden yaitu skala 1 sebanyak 4 (18.2\%) responden, skala 2 sebanyak 5 (22.7\%) responden, skala 3 sebanyak 7 $(31.8 \%)$ responden, skala 4 sebanyak $5(22.7 \%)$ responden, dan skala 5 sebanyak 1 (4.5\%) responden.

4. Uji Normalitas Data

Tabel 4

Uji Normalitas Data

\begin{tabular}{cccc}
\hline & \multicolumn{3}{c}{ Shapiro-Wilk } \\
\cline { 2 - 4 } & Statistic & df & sig \\
\hline $\begin{array}{c}\text { Skala nyeri } \\
\text { sebelum } \\
\text { kompres jahe } \\
\begin{array}{c}\text { Skala nyeri } \\
\text { setelah } \\
\text { kompres jahe }\end{array}\end{array}$ & 0.921 & 22 & 0.078 \\
\hline
\end{tabular}

Tabel di atas menunjukkan bahwa skala nyeri sendi sebelum kompres jahe memiliki nilai $p=0.078$ dan skala nyeri sendi setelah kompres jahe memiliki nilai $p=0.062$. Karena nilai $p$ pada kedua data tersebut $>0.05$ maka disimpulkan bahwa data berdistribusi normal. 
5. Analisis Efektifitas Kompres Jahe Terhadap Skala Nyeri

Tabel 4.

Hasil Uji Paired t-Test

Analisis Efektifitas Kompres Jahe Terhadap Skala Nyeri

\begin{tabular}{cccc}
\hline & Rerata \pm std & $\begin{array}{c}\text { Perbedaan } \\
\text { rerata } \pm \text { std }\end{array}$ & $p$ \\
\hline $\begin{array}{c}\text { Skala nyeri } \\
\text { sebelum } \\
\text { kompres } \\
\text { jahe }\end{array}$ & $4.18 \pm$ & & \\
Skala nyeri & 1.053 & $1,455 \pm$ & 0.000 \\
$\begin{array}{c}\text { setelah } \\
\text { kompres } \\
\text { jahe }\end{array}$ & $2.73 \pm$ & 0.671 & \\
\hline
\end{tabular}

Tabel di atas menunjukkan ratarata skala nyeri sebelum pemberian kompres jahe adalah 4.18 dengan standar deviasi \pm 1.053. Sedangkan rata-rata skala nyeri setelah dilakukan kompres jahe adalah 2.73 dengan standar deviasi \pm 1.162. Perbedaan rerata skala nyeri sebelum dan setelah pemberian kompres jahe adalah 1.455 dengan standar deviasi \pm 0.671 . Nilai $p$ adalah 0.000 .

\section{PEMBAHASAN}

Asam urat merupakan sisa hasil metabolisme tubuh, yaitu produk pemecahan metabolisme purin (Soeroso dan Algristian, 2011). Menurut Tarkeltaub sebagaimana dikutip oleh Lemone, Burke, dan Bauldoff (2015) normalnya keseimbangan terjadi antara produksi dan ekskresi asam urat, dengan sekitar dua pertiga jumlah yang dihasilkan dikeluarkan oleh ginjal dan sisanya dalam feses. Kadar asam urat serum normalnya dipertahankan antara 3.5 dan 7.0 $\mathrm{mg} / \mathrm{dL}$. Tingginya kadar asam urat bisa disebabkan karena produksi asam urat yang berlebih, menurunnya ekskresi asam urat melalui ginjal, atau mungkin karena keduanya (Helmi, 2012). Asam urat yang tinggi kemudian akan menumpuk dalam ruang sendi dan menyebabkan gangguan pada struktur sendi (Soeroso dan Algristian, 2011). Terdapat banyak faktor yang mempengaruhi tingginya kadar asam urat, diantaranya usia, jenis kelamin, riwayat medikasi, obesitas, konsumsi purin dan alkohol.

Berdasarkan usia pada penelitian ini didapatkan mayoritas responden yang menderita asam urat berusia $50-60$ tahun, yaitu sebanyak 12 $(54.55 \%)$. Hal ini sesuai dengan penelitian Wuragian, Bidjuni, dan Kallo (2014) yang menyatakan bahwa sebanyak $23.3 \%$ penderita asam urat berusia 30-49 tahun, 40\% berusia 50-64 tahun, dan $36.7 \%$ berusia > 65 tahun. Berdasarkan penelitian tersebut dapat diamati bahwa mayoritas penderita asam urat berusia 50-64 tahun. Begitu juga penelitian Astuti dan Tjahjono (2013) yang menyatakan bahwa penderita asam urat terbanyak adalah kelompok usia 48-60 tahun yaitu sebesar $45.0 \%$, dibandingkan kelompok usia 34-47 tahun yaitu $30 \%$ dan kelompok usia 20-33 tahun yaitu 25\%. Menurut Ode (2012) usia merupakan faktor resiko tingginya kadar asam urat dalam tubuh, karena ketika seseorang bertambah tua maka akan terjadi perubahan berupa penurunan proses metabolisme dalam tubuh. Semakin bertambah usia, jika seseorang mengkonsumsi protein dalam jumlah banyak maka akan berakibat terjadinya penimbunan purin dalam darah (Sholihah, 2014). Pendapat lain mengungkapkan bahwa peningkatan usia menjadi faktor resiko tingginya kadar asam urat dikarenakan adanya penurunan fungsi ginjal, peningkatan pemakaian obat diuretik, dan obat lain yang dapat meningkatkan kadar asam urat serum. Menurut Sutrani dalam penelitian Andry, Saryono, 
dan Upoyo (2009) tubuh memiliki suatu enzim yang disebut dengan enzim urikinase yang berfungsi untuk mengoksidasi asam urat menjadi alotonin yang memudahkan asam urat untuk dibuang. Enzim ini akan menurun seiring dengan bertambahnya usia. Jika pembentukan enzim ini terganggu maka kadar asam urat dalam darah akan naik. Berdasarkan beberapa pendapat di atas dapat disimpulkan bahwa penderita asam urat mayoritas berusia 50-60 tahun yang dapat disebabkan karena penurunan proses metabolisme, penurunan fungsi ginjal, dan penurunan enzim urikinase.

Berdasarkan jenis kelamin didapatkan hasil bahwa mayoritas penderita asam urat berjenis kelamin perempuan, yaitu sebanyak $13(59.10 \%)$. Hal ini sesuai dengan penelitian Kalim (2013) yang mendapatkan hasil bahwa responden yang menderita asam urat sebanyak $94.9 \%$ berjenis kelamin perempuan. Berdasarkan jenis kelamin yang mengalami peningkatan asam urat umumnya adalah laki-laki, akan tetapi wanita sebenarnya lebih beresiko (Breuer, et al., 2017). Laki-laki memiliki tingkat serum asam urat lebih tinggi dibanding wanita, sehingga meningkatkan resiko laki-laki mengalami peningkatan asam urat. Sebelum usia 30 tahun asam urat lebih banyak terjadi pada laki-laki dibandingkan wanita, namun resiko tingginya asam urat menjadi sama antara laki-laki dan wanita setelah usia 60 tahun. Wanita mengalami peningkatan resiko asam urat setelah menopause, resiko mulai meningkat pada usia 45 tahun ke atas akibat penurunan level estrogen, karena estrogen memiliki efek urikosurik (Widyanto, Sakit, dan Blitar, 2009). Pada penelitian ini mayoritas perempuan yang mengalami peningkatan asam urat adalah perempuan yang berusia lebih dari 50 tahun, sehingga tingginya asam urat pada responden perempuan tersebut dapat disebabkan karena penurunan level estrogen akibat menopause ataupun karena faktor usia.

Berdasarkan skala nyeri sebelum dilakukan kompres jahe, mayoritas responden mengalami nyeri skala 4 dan 5 dengan persentase yang sama, yaitu $31.8 \%$, skala nyeri tertinggi adalah skala 6 sebanyak 2 (9.1\%) responden dan skala terendah adalah skala 2 sebanyak 1 (4.5\%) responden. Sedangkan skala nyeri setelah kompres jahe mayoritas pada skala 3 sebanyak 7 (31.8\%) responden, skala tertinggi adalah skala 5 sebanyak 1 (4.5\%) responden, dan skala terendah adalah skala 1 sebanyak 4 (18.2\%). Berdasarkan data tersebut dapat diamati bahwa terjadi penurunan skala nyeri setelah diberikan kompres jahe.

Berdasarkan hasil uji paired t-test didapatkan nilai rata-rata skala nyeri sebelum dilakukan kompres jahe adalah 4.18 sedangkan rata-rata skala nyeri setelah dilakukan kompres jahe adalah 2.73, terjadi penurunan rata-rata skala nyeri antara sebelum dan setelah diberikan kompres jahe sebesar 1.455. Nilai $p$ dalam uji ini adalah $\mathrm{p}=0.000$ yang berarti terdapat perbedaan yang bermakna skala nyeri antara sebelum dan setelah dilakukan pemberian kompres jahe. Hal ini sesuai dengan penelitian yang telah dilakukan oleh Wijayanto, Purwanti, dan Isro'in (2017) dengan hasil seluruh responden yang diberikan kompres hangat mengalami penurunan intensitas nyeri dari 5.55 menjadi 2.95. Begitu juga penelitian yang telah dilakukan oleh Masyhurrosyidi, Kumboyono dan Utami (2014) mendapatkan hasil skala nyeri tertinggi sebelum diberikan kompres rebusan jahe adalah 8 sedangkan skala nyeri tertinggi setelah diberikan kompres 
rebusan jahe adalah 5, secara keseluruhan rata-rata penurunan skala nyeri sebesar 2,75. Berdasarkan hasil penelitian ini dan didukung oleh penelitian yang lain dapat diketahui bahwa terjadi penurunan skala nyeri setelah diberikan kompres jahe.

Menurut Wulanniati (2017) jahe yang digunakan untuk kompres mempunyai beberapa manfaat, salah satunya adalah mengurangi nyeri karena sifat jahe yang hangat. Menurut Potter dan Perry (2005) kompres hangat dapat menghambat reseptor nyeri pada serabut saraf besar dimana akan mengakibatkan terjadinya perubahan mekanisme yang dapat memodifikasi dan merubah sensasi nyeri yang datang sebelum sampai ke korteks serebri, sehingga sensasi nyeri dapat berkurang. Selain mengurangi nyeri, menurut Wulanniati (2017) jahe juga mempunyai efek mengurangi peradangan. Menurut Herliana (2013) jahe mengandung komponen aktif yaitu gingerol, gingerdione, dan zingeron yang mempunyai efek antiradang. Cara kerja zat-zat tersebut adalah menghambat leukotriene dan prostaglandin yang merupakan mediator radang. Seiring dengan penurunan peradangan tersebut maka akan terjadi penurunan rasa nyeri. Wulanniati (2017) juga menyebutkan bahwa efek jahe yang panas menyebabkan terjadinya vasodilatasi pembuluh darah sehingga meningkatkan peredaran darah. Peningkatan aliran darah dapat meningkatkan pembuangan produk-produk inflamasi seperti bradikinin, histamin, dan prostaglandin yang dapat menimbulkan nyeri lokal (Smeltzer dan Bare, 2002).

Berdasarkan beberapa pendapat di atas dapat disimpulkan bahwa kompres jahe dapat mengurangi peradangan melalui peran dari beberapa zat aktif yang berfungsi sebagai antiradang, selain itu jahe juga berfungsi mengurangi nyeri dengan memanfaatkan efek panas dari jahe yang dapat menghambat reseptor nyeri pada serabut saraf, dan efek panas jahe juga dapat memberikan efek vasodilatasi pada pembuluh darah yang dapat meningkatkan aliran darah sehingga pembuangan produk-produk antiradang juga meningkat.

\section{KESIMPULAN}

1. Penderita asam urat mayoritas berusia 50-60 tahun, yaitu sebanyak $54.55 \%$ dan berjenis kelamin perempuan, yaitu sebanyak $59.10 \%$.

2. Skala nyeri sebelum kompres jahe mayoritas skala 4 dan 5 dengan persentase yang sama, yaitu $31.8 \%$, skala nyeri tertinggi adalah skala 6 sebanyak $9.1 \%$ dan skala terendah adalah skala 2 sebanyak $4.5 \%$.

3. Skala nyeri setelah kompres jahe mayoritas skala 3 sebanyak $31.8 \%$, skala tertinggi adalah skala 5 sebanyak $4.5 \%$, dan skala terendah adalah skala 1 sebanyak $18.2 \%$.

4. Rata-rata skala nyeri sebelum dilakukan kompres jahe adalah 4.18 sedangkan rata-rata skala nyeri setelah dilakukan kompres jahe adalah 2.73, terjadi penurunan rata-rata skala nyeri antara sebelum dan setelah diberikan kompres jahe sebesar 1.455. Nilai $p$ berdasarkan uji paired $t$-test adalah $p=0.000$ yang berarti terdapat perbedaan yang bermakna penurunan skala nyeri antara sebelum dan setelah dilakukan pemberian kompres jahe.

\section{SARAN}

1. Bagi penderita asam urat diharapkan dapat menerapkan metode penanganan nyeri nonfarmakologi dengan menggunakan kompres jahe, 
karena kompres jahe telah terbukti efektif untuk menurunkan nyeri sendi pada penderita asam urat.

2. Bagi tenaga kesehatan diharapkan dapat meningkatkan pemberian informasi kepada warga terkait manajemen nyeri nonfarmakologi menggunakan kompres jahe.

3. Bagi peneliti selanjutnya diharapkan dapat menggunakan hasil penelitian ini sebagai data awal dalam melakukan penelitian selanjutnya dan dapat melakukan penelitian yang lebih mendalam tentang kompres jahe.

\section{DAFTAR PUSTAKA}

Andry, Saryono, dan A.S. Upoyo. 2009. Analisis Faktor-Faktor yang Mempengaruhi Kadar Asam Urat pada Pekerja Kantor di Desa Karang Turi, Kecamatan Bumiayu, Kabupaten Brebes. Jurnal Keperawatan Soedirman, Volume 4. No. 1. Diakses pada tanggal 17 Maret 2018.

Astuti, S. dan H. Tjahjono. 2014. Faktor-Faktor Yang Memengaruhi Kadar Asam Urat (Gout) Pada Laki-Laki Dewasa Di Rt 04 Rw 03 Simomulyo Baru Surabaya. Jurnal Stikes Williamboot. Diakses pada 17 Maret 2018.

Badan Pusat Statistik Jakarta Pusat. 2010. Statistik Indonesia tahun 2010. Badan Pusat Statistik, Jakarta Pusat.

Breuer, G.S, Y. Schwartz, Y. FreierDror, G. Nesher. 2017. Uric Acid Level as Predictor of Mortality in the Acute Care Setting of Advanced Age Population. Eur J Intern Med. Diakses pada tanggal 17 Maret 2018.

Helmi, Z. N. 2012. Buku Ajar Gangguan Muskuloskeletal. Salemba Medika, Jakarta.
Herliana, E. 2013. Penyakit Asam Urat Kandas Berkat Herbal. Fmedia, Jakarta.

Izza, S. 2014. Perbedaan Efektifitas Pemberian Kompres Air Hangat dan Pemberian Kompres Jahe terhadap Penurunan Nyeri Sendi pada Lansia di Unit Rehabilitasi Sosial Wening Wardoyo Ungaran. Jurnal STIKES Ngudi Waluyo Ungaran. Diunduh 28 Maret 2018.

Kalim, H. 2011. Identifikasi Hubungan Pola Asupan Protein Hewan dengan Resiko Gout Arthritis di Kota Batu. digilib.upi.edu. Diakses pada tanggal 27 Maret 2018.

Lemone, P., M.Burke, dan Bauldoff. 2015. Buku Ajar Keperawatan Medikal Bedah, Edisi 5, Vol. 4. EGC, Jakarta.

Masyhurrosyidi, H. Kumboyono dan Y.W. Utami. 2014. Pengaruh Kompres Hangat Rebusan Jahe Terhadap Tingkat Nyeri Subakut dan Kronis pada Lanjut Usia dengan Osteoarthtritis Lutut di Puskesmas Arjuna Kecamatan Klojen Malang Jawa Timur. Jurnal Kesehatan FKUB. Diakses pada 17 Maret 2018.

Ode, S.L. 2012. Asuhan Keperawatan Gerontik. Nuha Medika, Yogyakarta.

Potter dan Perry. 2005. Buku Ajar Fundamental Keperawatan. Edisi 4. EGC, Jakarta.

Putri, S., D. Rahmayanti, dan N. Diani. 2017. Pengaruh Pemberian Kompres Jahe Terhadap Intensitas Nyeri Gout Artritis Pada Lansia Di Pstw Budi Sejahtera Kalimantan Selatan. Jurnal Keperawatan Universitas Lambung Mangkurat. Diakses pada tanggal 28 Maret 2018. 
Riskesdas. 2013. Riset Kesehatan Dasar tentang Penyakit Sendi. www.litbang.depkes.go.id. Diakses pada tanggal 10 Maret 2018.

Rusnoto, Cholifah dan Retnosari. 2015. Pemberian Kompres Hangat Memakai Jahe untuk Meringankan Skala Nyeri pada Pasien Asam Urat di Desa Kedungwungu Kecamatan Tegowanu Kabupaten Grobogan. Jurnal STIKES Muhammadiyah Kudus. Diakses pada tanggal 7 Maret 2018.

Sholihah, F.M. 2014. Diagnosis and Treatment Gout Arthritis. J Major. Diakses pada tanggal 7 Maret 2018.

Smeltzer, S.C. dan B.G. Bare. 2002. Buku Ajar Keperawatan Medikal Bedah. Edisi ke-8. EGC, Jakarta.

Soeroso, Joewono dan Algristian. 2011. Asam Urat. Dilihat pada tanggal 10 Maret 2018. https://books.google.co.id/boo ks?

Widyanto, F.W, R. Sakit, dan A. Blitar. 2009. Artritis Gout dan Perkembangannya. Naskah Publikasi Bantul. Diakses pada tanggal 28 Maret 2018.
Wijayanto, A., L. E. Purwanti, dan L. Isro'in. 2017. Pengaruh Kompres Hangat dengan Jahe terhadap Penurunan Skala Nyeri Osteoartritis. Jurnal Kesehatan Universitas Muhammadiyah Ponorogo. Diakses pada tanggal 22 Maret 2018.

Wulanniati, S. 2017. Penerapan Terapi Non Farmakologi Kompres Jahe terhadap Nyeri Lutut pada Lansia di Daerah Kelurahan Sambiroto Semarang. Jurnal Universitas Negeri Semarang. Diakses pada tanggal 7 Maret 2018.

Wurangian, M., H. Bidjuni, dan V. Kallo. 2013. Pengaruh Kompres Hangat terhadap Penurunan Penurunan Skala Nyeri Pada Penderita Gout Artritis di Wilayah Kerja Puskesmas Bahu Manado. Volume 4 No 2. Jurnal Kesehatan Universitas Sam Ratulangi Manado. Diakeses pada tanggal 11 Maret 2018.

\footnotetext{
${ }^{1}$ Dosen Akper Panti Kosala Surakarta

${ }^{2}$ Mahasiswa Akper Panti Kosala Surakarta
} 